Rev. Mus. Argentino Cienc. Nat., n.s.

7(1): 7-15, 2005

Buenos Aires, ISSN 1514-5158

\title{
Anatomy of a new probable pteridosperm stem from the Late Carboniferous of Argentina
}

\author{
Silvia N. CÉSARI ${ }^{1}$, Sergio ARCHANGELSKY ${ }^{1}$ \& Juan C. VEGA ${ }^{2}$ \\ ${ }^{1}$ Museo Argentino de Ciencias Naturales B. Rivadavia, Av. Angel Gallardo 470, C1405DJR, Buenos Aires, \\ Argentina. scesari@macn.gov.ar. ²Virasoro 1531, (2000) Rosario, Argentina.
}

\begin{abstract}
A new genus and species, Amosioxylon australis, based on an anatomically preserved stem from the Late Carboniferous Jejenes Formation, Argentina, is described. The specimen is six $\mathrm{cm}$ in diameter and has some features usually found in pteridosperms, including the presence of several vascular segments surrounded by secondary xylem. The pycnoxylic wood resembles progymnosperms and the tissue between the vascular strands, with reticulate thickenings and pits, is similar to the transfusion tissue found in extant conifers and cycads. According to the available evidences a relationship with primitive pteridosperms is suggested.
\end{abstract}

Key Words: Late Carboniferous, Gondwana, stem, anatomy.

The Jejenes Formation crops out at the western flank of the Sierra Chica de Zonda (San Juan province) and it includes abundant fossil plant remains that are referred to the Nothor-hacopterisBotrychiopsis-Ginkgophyllum (NBG) biozone, of Late Carboniferous age (Archangelsky et al., 1987). Recent studies of fertile structures found at Quebrada de la Mina locality (Cladera et al., 2000) were related to triphyllopteroid and rhacopteroid fronds demonstrating their affinity to the seed ferns (Vega \& Archangelsky, 1996, 1997, 2001). Since then, Quebrada de la Mina has become an important site in Gondwana because of the fertile pteridosperms found there, the first in the Late Carboniferous of the southern hemisphere. New collections from the same plant bearing strata include the discovery of an anatomically preserved stem, described here, that illustrates the presence of petrifactions, compressions and impressions of fertile fronds and leaves in this level.

At present, the Jejenes Formation probably has the highest plant biodiversity of any stratigraphic unit in the Argentine Carboniferous. The palynological associations are characterized by monosaccate pollen grains and spores (Gutierrez

\& Césari, 1985; Césari \& Bercowski, 1997) that can be referred to the Raistrickia densa-Convolutispora muriornata Biozone of northwestern Argentina.

\section{MATERIAL AND METHODS}

The stem occurs as a permineralization of silica in the form of chalcedony as the embedding mineral with carbonate as a second phase filling the fissures. The brittle axis was embedded in plastic resin prior to cutting into 6 thin slices. Small fragments of tissues were observed with scanning electron microscopy (SEM) whereas others were macerated with $\mathrm{HF}$ and $\mathrm{HCl}$ and mounted in glycerine-jelly. Photography with transmitted light was made using a Nikon SMZ2T stereoscopic microscope and an Olympus BX 51 microscope. The specimen and the slides used in this study are housed in the Paleobotanical Collection of the Museo Argentino de Ciencias Naturales B. Rivadavia (BAPB and BAPBPm), under the acquisition numbers BAPB 12850 and BAPBPm 435-440.

\section{SYSTEMATICS}

Amosioxylon Césari, Archangelsky \& Vega, gen. nov.

(Figs. 1-21)

Diagnosis : Stem with multiple vascular strands, each strand containing both primary and secondary xylem tissues embedded in a ground tissue. Vascular columns in transverse view of variable size and shape. Primary xylem two or three ribbed. Secondary xylem with tracheids having alternate bordered pits and oblique elliptical apertures. Heterocellular rays with transverse tracheids having spiral or reticulate thickenings. Cross-fields with multiple pit pairs. 
Type: Amosioxylon australis Césari, Archangelsky \& Vega sp. nov.

Derivatio nominis: The genus is named after the late Prof. Dr. Arturo J. Amos, a distinguished researcher of the Carboniferous in Argentina who made several contributions on the Sierra Chica de Zonda area.

\section{Amosioxylon australis Césari, Archangelsky \& Vega, sp. nov.}

(Figs. 1-21)

Holotype: BAPB 12850 and the thin sections BAPBPm 435-440

Repository: Palaeobotanical Collection, Museo Argentino de Ciencias Naturales, «B. Rivadavia», Argentina.

Type locality : Quebrada de la Mina, San Juan province, Argentina.

Stratigraphic horizon: Jejenes Formation. Late Carboniferous.

Derivatio nominis: The specific name refers to the southern origin of the stem. Description: As seen in cross section the

specimen (ca. $6 \mathrm{~cm}$ in diameter and $13 \mathrm{~cm}$ in length) consists of at least four strands of vascular tissue that vary in size and shape $(A, B$, $C$ and $D$ in scheme and Fig. 2). One has an oval outline (Fig. 2D), and is poorly preserved, although the presence of a two ribbed primary xylem may be inferred by two protoxylem poles located along the structure. Another segment has three-ribbed primary xylem and secondary xylem with a marked centrifugal development (Fig. 4). The vascular columns represented by $A$ and $C$ in figure 2 are approximately circular in transverse outline. An incipient trace is seen in one of the biribbed primary xylem strands (Fig. 3 arrow).

The primary xylem as seen in TS shows two or three lobes (Figs. 3 and 4) and is represented exclusively by tracheids. Discrete protoxylem strands occur near the tips of xylem ribs, however due to poor preservation it is impossible to determine their number and exact arrangement. Protoxylem or early metaxylem elements are $10 \mu \mathrm{m}$ in diameter. Metaxylem tracheids vary from 20 to 50 $\mu \mathrm{m}$ in diameter. Centrifugal secondary xylem extends for up to about $18 \mathrm{~mm}$ in a radial file. There is no evidence of growth rings. The secondary tissue includes tracheids and narrow rays (Fig. 6). Tracheids appear rectangu-lar and range in diameter from approximately $15 \mu \mathrm{m}$ to $35 \mu \mathrm{m}$ in radial direction and $50 \mu \mathrm{m}$ to $70 \mu \mathrm{m}$ in tangential direction. Vascular rays usually occur every $3-5$ rows of tracheids, are heterocellul-ar and include ray tracheids. Rays are usually one,

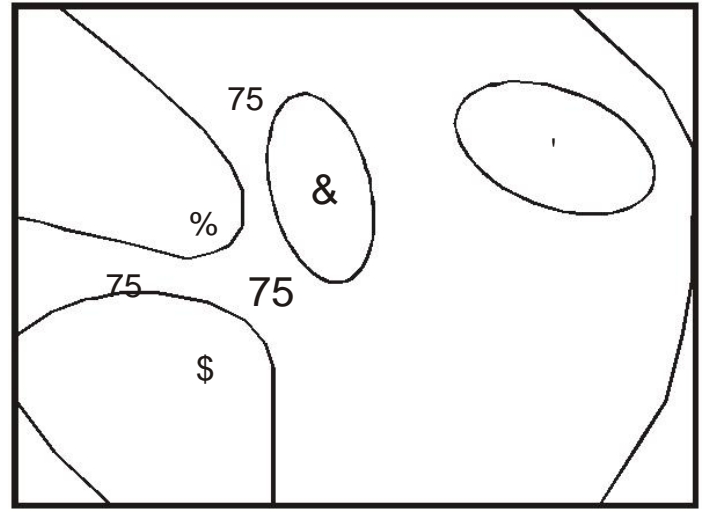

Scheme of Fig. 2, showing the vascular segments and distribution of transfusion tissue (TR).

but sometimes two or three, cells wide and up to 10 cells high (Fig. 10). Transverse tracheids have spiral or reticulate thickenings combined with areolate pits (Fig. 18, 19 and 21). Pitting on the ray cells is simple or bordered, confined to the radial walls (Fig. 17). Secondary xylem tracheids are characterized by up to triseriate circular bordered pit- pairs, with oblique elliptical apertures (Fig. 9, 11 and 12), apparently on both tangential and radial walls. The cross -fields show 5-10 simple circular pits (Figs. 7 and 8) arranged approximately in two or three horizontal rows. Longitudinal tangential sections of the secondary xylem show «patches» of short tracheids with reticulate thickenings combined with areolate pits (Figs. 13- 15). Although distinctive vascular traces are not preserved, the «patches» could be related with some sort of vascular emission. The ground tissue, located surrounding the secondary xylem of the vascular strands (see scheme), is composed of elongated parenchymatic cells (up to $130 \mu \mathrm{m} \times 80 \mu \mathrm{m}$ ) and short tracheids (usually $40 \mu \mathrm{m} \times 40 \mu \mathrm{m}$ ), of a polygonal contour, reticulate thickening of walls and bordered pits (Fig. 5) si-milar to transfusion tissue. Petioles and cortex not preserved.

Longitudinal and radial sections of the secondary tissue show evidence of fungal activity (Fig. 20) in the tracheids. There are spherical bodies about 10-20 $\mu \mathrm{m}$ in diameter. It may be attributed to some type of chytrid zoosporangium like those described by Smooth \& Taylor (1983). The Order Chytridiales corresponds to unicellular organisms that in their vegetative phase have hyphae. They occur mainly in fresh water, although there are representatives that occur in soil and a few in the marine environment. 

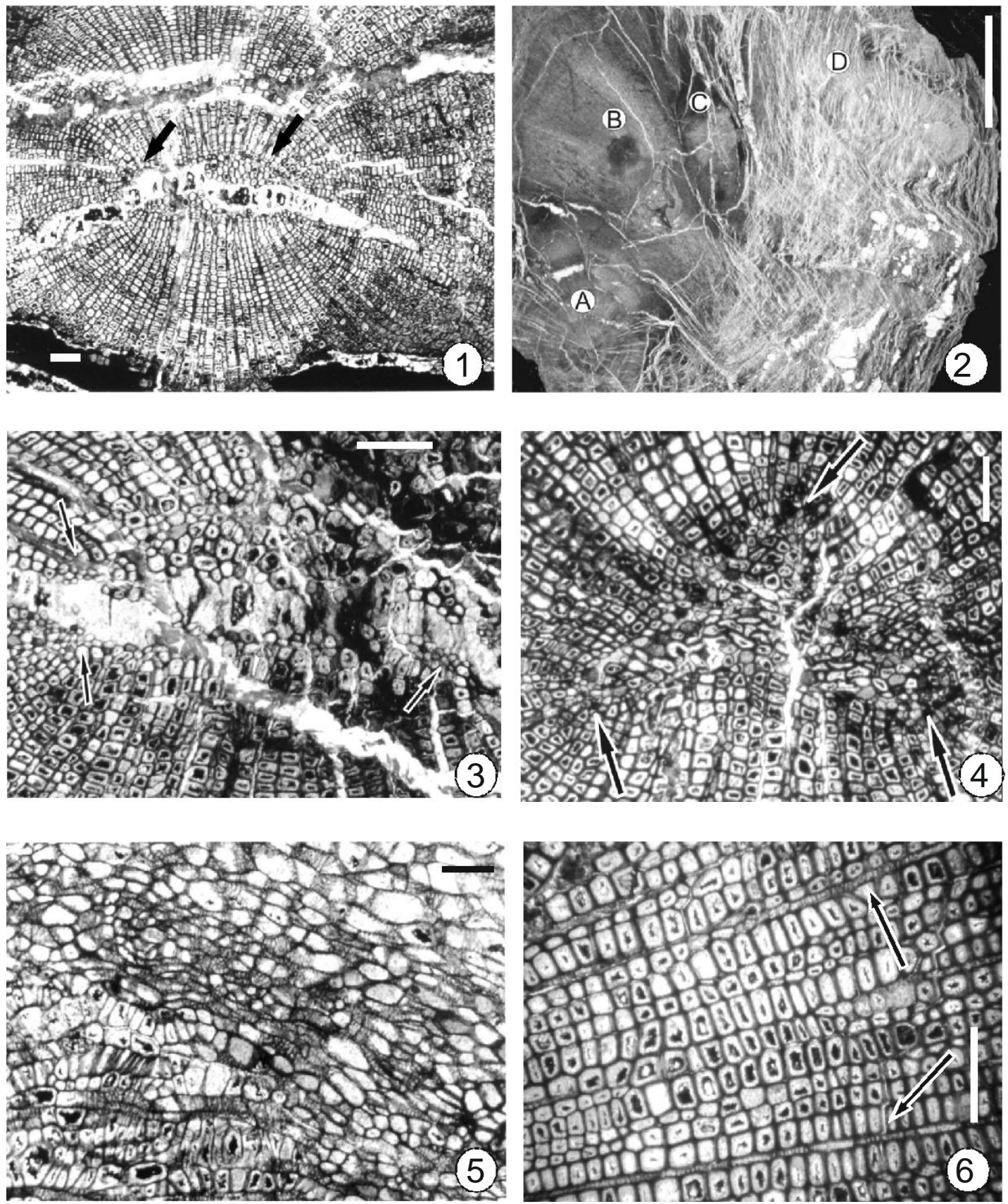

Figs. 1-6. Amosioxylon australis gen. et sp. nov. 1, Transverse section of the two -ribbed (arrows) primary xylem of the vascular segment $C$ in Fig. 2. BAPB Pm 436. 2, Cross section of stem showing four vascular segments (A -D) surrounded by ground tissue (see scheme in text). BAPBPm 435. 3, Primary vascular bundles (at arrows) of the vascular segment A in Fig. 2. BAPB 435. 4, Three-ribbed primary xylem of the vascular segment B in Fig. 2. BAPB 435. 5, Transverse section of the ground tissue showing tracheids with reticulate thickenings and merged parenchymatic cells continuous with the tracheids of the secondary xylem (at bottom). BAPBPm 435. 6, Secondary xylem in transverse section showing rays tracheids (arrows). BAPBPm 435. Scale bar: Figs. 2-6 =100 $\mu \mathrm{m}, 1=1 \mathrm{~cm}$. 


\section{COMPARISONS}

Amosioxylon has four vascular strands, a condition rarely found in gondwanan Carboniferous stems. The tissue that surrounds the vascular segments contains tracheids with reticulate thickenings and pits which suggests that these cells may have functioned as transfusion tissue, similar to that found in extant conifers and cycads. According to Griffith (1957) transfusion tissue is generally associated with vascular bundles in leaves of gymnosperms (Esau, 1977). Walls of transfusion tracheids may be scalariform, reticulate or with bordered pits, but only the latter occur in the accessory transfusion tissue. Griffith (1957) mentions that occasionally a cell may have a combination of scalariform or reticulate with bordered pits like the cells illustrated in figures 14 and 15. Tracheids of the transfusion tissue are compact and mainly isodiametric, shortly cylindrical in shape while in the accessory transfusion tissue there are wide intercellular spaces. This accessory transfusion tissue is presently found only in the leaves of some species of Ginkgo, Cycas and Podocarpus.

Most early descriptions of transfusion tissue were concerned with whether it is modified mesophyll parenchyma or part of the vascular system, the remnant of ancestral centripetal xylem. Langdon (1920) described curiously reticulate tracheidal elements in Dioon spinulosum forming continuous vessels or isolated patches on the upper side of the foliar trace where the primary tissue would naturally appear. Worsdell (1896) also called attention to the occurrence of these tracheids resembling «transfusion tissue» in Macrozamia fraseri, and among the parenchyma cells between successive vascular rings in Encephalartos.

On the other hand, special attention must be paid to the presence of rays with tracheids in our specimen. Transverse tracheids with spiral thickenings are present in Pseudotsuga and a few Picea and Larix species, while reticulate thickenings are common in Pinus. According to Greguss (1955) the presence and structure of transverse tracheids constitutes a feature of diagnostic value that may be interpreted as a modern character in gymnosperms. However, Beck (1970) pointed out that the gymnospermous wood structure appeared in the Late Devonian genus Callixylon Beck. This author mentioned the presence of ray tracheids in Callixylon, a feature known elsewhere only in the Coniferales. Beck (1970) described in the ray tracheids of $C$. erianum Arnold a helical wall layer superimposed on that with bordered pits, resembling a structure found in the extant conifer Sequoia.

Two other Paleozoic Argentinian stems, Abietopitys patagonica Archangelsky and $A$. crassiradiata Archangelsky from the Permian of Patagonia, show rays with thickenings (Archangelsky, 1960).

Amosioxylon is a stem that has characters comparable with the two main groups of primitive gymnosperms, viz. Progymnosperms and Pteridosperms (or seed ferns).

\section{Comparisons with Progymnosperms}

Progymnosperms were originally defined as «plants having gymnospermic secondary wood and pteridophytic reproduction» (Beck, 1962). Later Beck \& Wight (1988) characterized the progymnosperm vegetative structure by pseudomonopodial branching, vascular system represented by a ribbed protostele, a medullated protostele or a eustele from which leaf traces diverge radially from the ends of ribs or from axial bundles, and compact secondary xylem with tracheids and rays. Pycnoxylic wood as that found in Amosioxylon is characteristic of modern conifers and it was found earlier in the Devonian progymnosperm Callixylon (= Archaeopteris). Beck (1970) described these big stems with compact pitted secondary xylem of coniferophytic appearance and narrow rays characterized by ray tracheids. In $C$. erianum there are ray tracheids with bordered pit-pairs and superimposed helical wall layer, similar to those of the living conifer

\section{Sequoia.}

Three orders, viz. Aneurophytales, Archaeopteridales and Protopytiales have been recognized in the progymnosperms (Beck \& Wight, 1988). The Devonian order Aneurophytales is anatomically characterized by a ribbed protostelic primary vascular system, mesarch primary xylem, a bifacial cambium, circular bordered pitting on metaxylem and secondary xylem tracheid walls and fibers or/and sclereids in the cortex. The order Archaeopteridales had a circumpolar distribution during the Upper Devonian to Lower Mississippian and is anatomically characterized by eusteles in large axes, protosteles or medullated protosteles in smaller axes and mesarch primary xylem. Scheckler \& Banks (1971) suggested that the Aneurophytales and Archeopteridales are related. Support for this relationship comes from the presence of ray tracheids with aligned and grouped bordered pits on the radial walls of some genera in both orders, as well as the presence of bifacial vascular cambium (Stewart \& Rothwell, 1993). 

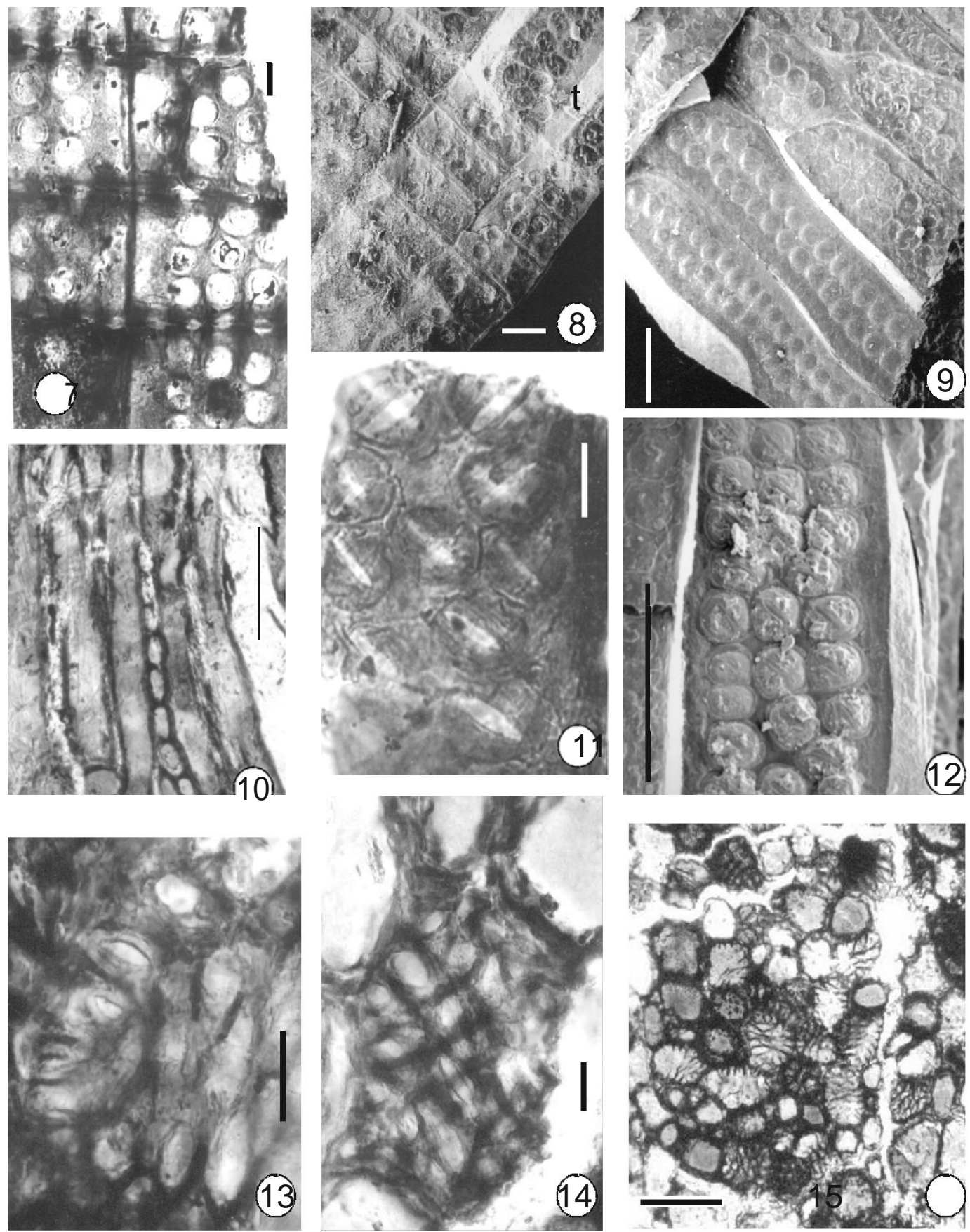

Figs. 7-15. Amosioxylon australis gen. et sp. nov. 7, Radial section of secondary xylem showing crossfield pits (in fragment dissociated with HF). BAPBPm 437. 8, Radial section of secondary xylem showing obliquely oriented ray tracheids and cross-fields, $t$ : tracheid. 9 , Biseriate pitted tracheids of secondary xylem in radial section. 10, Tangential section of secondary xylem containing uniseriate rays. BAPB Pm 438. 11, Detail of tracheid showing crossed slit-like apertures (in fragment dissociated with HF). BAPBPm 437. 12, Tracheids with triseriate pitting showing slit-like apertures. SEM. 13 and 14 , Detail of one tracheid in tangential section of secondary xylem with reticulate thickenings and areolate pits. BAPBPm 438. 15, Detail of group of short tracheids with reticulate thickenings and areolate pits in tangential section of secondary xylem. BAPBPm 438. Scale bar: Figs. 7 and $8=20 \mu m$, 9 and $12=50 \mu \mathrm{m}, 11,13$ and $14=10 \mu \mathrm{m}, 10$ and $15=100 \mu \mathrm{m}$. 


\section{Comparisons with Pteridosperms}

The general anatomical structure of Amosioxylon with more than one vascular segment, considered to be a primitive character, resembles Paleozoic pteridosperms of the Northern Hemisphere. Stems of this group normally have manoxylic wood. However, several early seed plants are represented by stems and attached petioles having features of cycadophytic gymnosperms, with a more pycnoxylic secondary tissue.

Our specimen resembles the original description of Bostonia (Stein \& Beck, 1978) based on a single specimen in which only the center of the axis is preserved. Bostonia shows a ground tissue containing at least three bundles of primary xylem, each surrounded by its own cylinder of secondary xylem. Stein and Beck (1978) suggested that the presence of multiple vascular segments is a feature similar to Medullosales. However, the possibility that this type of «polystely» might be the result of a distal branching was also considered by Stein \& Beck (1978). The original specimen of Bostonia shares with Amosioxylon the presence of several, different-in-shape, vascular segments. However, later Stein \& Beck (1992) described a more complete specimen of Bostonia perplexa, that differs of our specimen. Stein \& Beck (1992) redefined Bostonia as a protostelic calamopityacean with medullosan-like vascular segments and suggested its inclusion in the Calamopityales, by the presence of Kalymma-type petioles.

Foliage of Diplothmema and Sphenopteridium types has been related to Calamopityales. Moreover, Taylor \& Taylor (1993) suggested that Triphyllopteris foliage may be a representative member of the Calamopityaleans or the Buteoxylonales. In our case, Triphyllopteris- type of foliage occurs at the same fossil site where Amosioxylon is found (Leguizamón \& Vega, 1991).

In transverse section stems of Medullosaceae are characterized by one to several segments of vascular tissue, and originally were considered polystelic. After an analysis of Basinger et al. (1974) this configuration is interpreted as a series of vascular segments of a single stele. In typical medullosae, unlike our specimen, each segment is elliptical to banded with a primary xylem characterized by abundant parenchyma, protoxylem oriented toward the external margin of stele, and secondary xylem encircling each segment and typically more developed toward the centre of the axis. In Medullosa leaf traces often are just branched steles, surrounded by secon-dary elements that are preserved up to the highest levels of the plant. This character is present in many species and has been interpreted as being primitive (Delevoryas, 1955). Medullosa endocentrica Baxter (1949) was interpreted by Hamer \& Rothwell (1988) as a vine bearing fronds with Eusphenopteris pinnules. The axes are two $\mathrm{cm}$ in diameter. Primary and secondary xylem of both vascular segments have a markedly endocentric development, and they are immersed in ground tissue representing a medulla. This ground tissue is composed of isodiametric parenchimatic cells continuous with the cortex. As in other medullosae the protoxylem is found only along the edge of the metaxylem.

Proximally in the stem, the secondary xylem surrounds each vascular segment, except where foliar traces diverge showing the primary xylem in contact with the ground tissue. This character, typical of the group, was not observed in Amosioxylon. A vascular cambium with fusiform cells and ray initials is preserved as a thin zone composed of cells with delicate walls at the periphery of the secondary xylem. Radially elongated initial rays are continuous with the wood, whereas fusiform initials are tangentially elongated.

On the other hand, most Permian medullosae differ from the Carboniferous representatives in the number and disposition of vascular segments. Medullosa stellata is one of the largest axes known (up to $50 \mathrm{~cm}$ in diameter). Some specimens show 43 individual central vascular segments, usually described as star rings. These segments are surrounded by a cylinder of primary and secondary xylem. The secondary xylem shows on both sides of the primary with a better developed centrifugal xylem.

\section{DISCUSSION}

Galtier (1988) recognized three types of stelar organization comparing aneurophytalean progymnosperms and early pteridosperms. Category 1 is common in Aneurophytales, in some Calamopityaceae, some putative early lyginopterids and Triradioxylon (attributed to the Buteoxy-lonaceae). It is characterized by a lobed protostele or actinostele, where the lobed anatomy reflects cladotaxy in the aneurophytaleans and phy-llotaxy in early pteridosperms.

Amosioxylon also has wood with primitive characters that were reported for progymnosperms. Galtier \& Scott (1991) pointed out that the pycnoxilic wood is a primitive feature of progymnosperms with regard to manoxylic wood with wide and high rays. Stein (1982) suggested that gymnospermic secondary vascular tissue is a derived (advanced) character that evolved only 

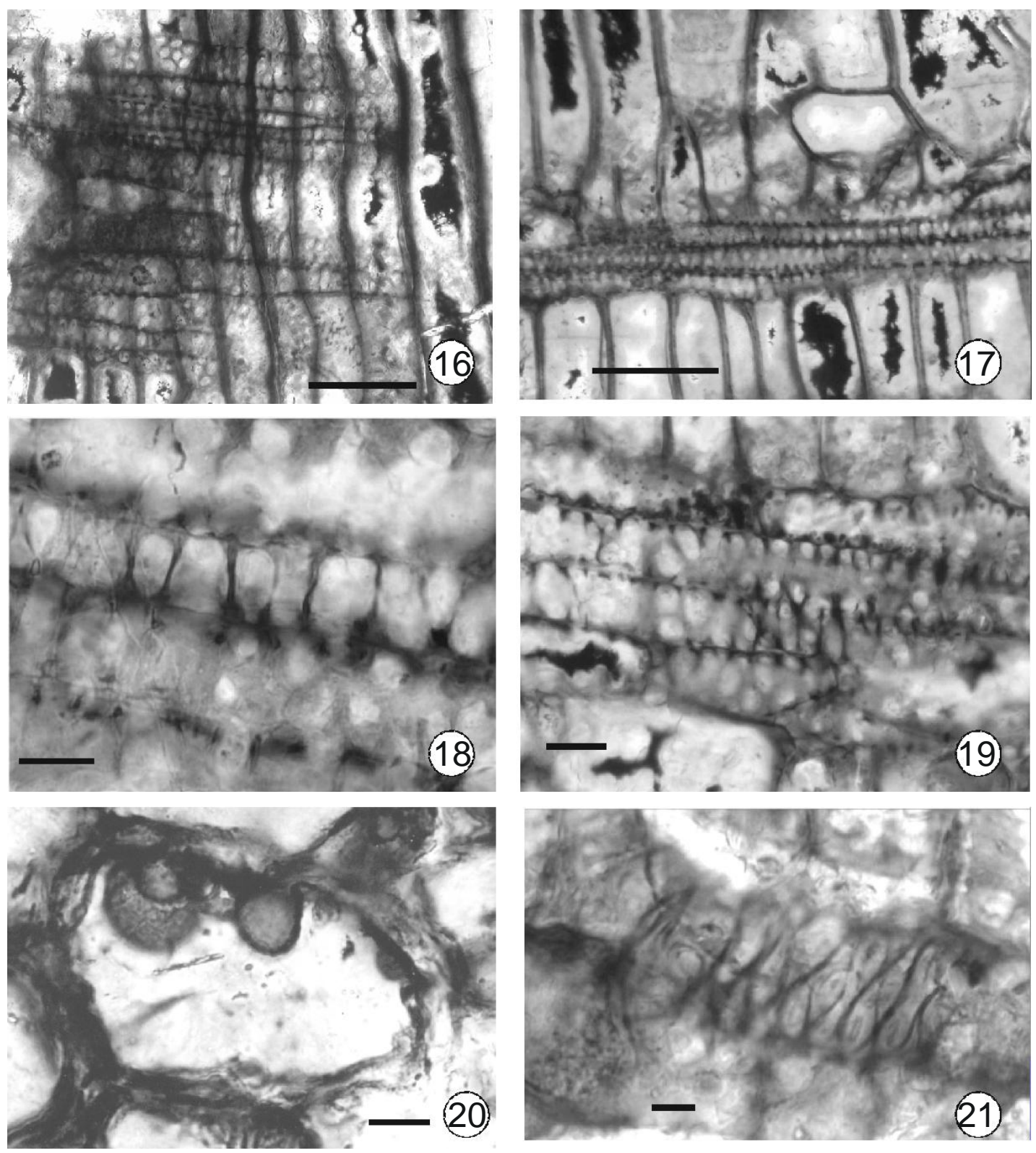

Figs. 16-21. Amosioxylon australis gen. et sp. nov. 16, Radial section of secondary xylem with heterocellular rays. BAPBPm 439. 17, Radial section of secondary xylem showing ray tracheids. BAPBPm 439. 18, Detail of ray tracheid with spiral thickening. BAPBPm 439. 19, Detail of ray tracheid with reticulate thickenings. BAPBPm 439. 20, Probable fungal bodies inside a secondary xylem cell. BAPBPm 438. 21, Detail of ray tracheid with reticulate thickenings and areolate pits. BAPBPm 439. Scale bar: Figs. 16 and $17=100 \mu \mathrm{m}, 18$ and $19=20 \mu \mathrm{m}, 20$ and $21=10 \mu \mathrm{m}$.

once in terrestrial plant history, and therefore has a much more important significance in the definition of the progymnosperms than the pteridophytic type of reproduction (a primitive character with respect to vascular plants in general). This criterion has been used by several authors to assign fossil wood to progymnosperms without knowing fertile structures of the whole plant. Beck \& Wight (1988) considered that restricting membership to the presence of the two original characters, gymnospermous secondary vascular tissues and the pteridophytic repro- 
duction, means to utilize only two out of many potentially useful characters.

According to Taylor \& Taylor (1993) the discovery of Upper Devonian cupulate seeds together with vegetative axes like that of aneurophytes suggest that these plants are transitional between progymnosperms and early seed ferns. On the other hand, Beck \& Wight (1988) considered that the gymnosperms are polyphyletic, with the seed ferns evolving from an aneurophyte ancestor and the cordaites and conifers from the Archaeopteridales. Aneurophytales seem to be good ancestors of the earliest seed ferns because many of these share in common protosteles and compact secondary xylem (Beck \& Wight, 1988).

The total assemblage of fossil plants includes, in the Quebrada de la Mina locality, fronds of Sphenopteris sarmientoi Vega \& lannuzzi, Fedekurtzia argentina (Kurtz) Archangelsky,

Diplothmema bodenbenderi (Kurtz) Césari, Rhacopteris szajnochai Kurtz, Nothorhacopteris argentinica (Geinitz) Archangelsky, Cardiopteridium ? sp., Fryopsis cf. F. frondosa (Goeppert) Wolfe, Botrychiopsis weissiana Kurtz emend. Archangelsky \& Arrondo, Triphyllopteris cuyana Leguizamon \& Vega Eusphenopteris sanjuanina (Kurtz) Césari emend. Césari et al. The following reproductive pteridosperm structures were also recognized: Rinconadia archangelskyi Vega, Austrocalyx jejenensis Vega \& Archangelsky, Polycalyx laterale Vega \& Archangelsky, Polycalyx tetramera Vega \& Archangelsky, Jejenia alata Vega \& Archangelsky. All these species are accompanied also by leaves of the gymnosperm Ginkgophyllum diazii Archangelsky \& Arrondo and Cordaites sp.

The finding in this locality of reproductive pteridosperm structures in organic connection with triphyllopteroid fronds allowed to define the southern family Austrocalyxaceae (Vega \& Archangelsky, 2001).

From a functional point of view, a multistranded anatomy has usually been related to vines while dense wood is a character of self supporting plants. The combination in our stem of these two characters along with the small diameter of the vascular segments and the relatively wide development of the secondary xylem is an interesting condition. Probably, this slender stem may have gained support by the dense wood. Nevertheless, growth forms in some pteridosperms is still not totally known and Dunn et al. (2003) suggested that some Medullosae may have been self-suporting until they reached a critical stem height, but then developed scrambling and climbing growth.

\section{CONCLUSIONS}

This species could be tentatively compared with the progymnosperm Archaeopteris (= Callixylon) which has a very similar dense wood but the presence of several two or three-ribbed vascular columns promotes comparisons with Bostonia, an early seed fern. The associated paleoflora includes leaves of cordaitales, fronds with attached fertile organs of pteridosperms and fronds referred to Sphenopteris, Eusphenopteris and Diplothmema among other taxa. The two last taxa were also related to pteridosperms in Ar-gentina (Césari et al., 1988 and Césari, 1997). Therefore, Amosioxylon is tentatively related to a group of primitive pteridosperms probably represented by the family Austrocalyxaceae (Vega \& Archangelsky, 2001) of southern Gondwana.

\section{ACKNOWLEDGEMENTS}

We are particularly grateful to Dr. B. MeyerBerthaud and Dr. W. DiMichele for coments made to an early version of this paper. We also thank the fruitful comments made by Drs. T. Taylor, J. Galtier and G. del Fueyo. This study was supported in part by the National Agency for the Promotion of the Science and Technology (PICT 04821 to S.N.C.). This is a contribution to the IGCP Project 471.

\section{BIBLIOGRAPHY}

Archangelsky, S. 1960. Estudio anatómico de dos especies del género Abietopitys Kräusel, procedentes de la Serie Nueva Lubecka (provincia de Chubut, Argentina). Acta Geol. Lilloana III: 331-342.

Archangelsky, S., C. Azcuy, C.R. Gonzalez \& N. Sabattini. 1987. Paleontología, bioestratigrafía y paleoecología de las cuencas Paganzo, Calingasta-Uspallata y Río Blanco. In S. Archangelsky (Ed.) El Sistema Carbonífero en la República Argentina. Academia Nacional de Ciencias Córdoba, pp. 293-301.

Basinger, J.F, G.W. Rothwell \& W.N. Stewart. 1974. Cauline vasculature and leaf trace production in medullosan pteridosperms. Am. J. Bot. 61: 10021015.

Baxter, R.W. 1949. Some pteridospermous stems and fructifications with particular reference to the Medullosae. Ann. Mo. Bot. Gard. 36: 287-352.

Beck, C.B. 1962. Reconstruction of Archaeopteris, and further consideration of its phylogenetic position. Am. Jour. Bot. 49:373-382.

- 1970. The appearance of gymnospermous structure. Biol. Rev. 45:379-400.

Beck, C.B. \& D.C. Wight. 1988. Progymnosperms. In C.B. Beck ed. Origin and evolution of gymnosperms. Columbia University Press, pp. 1-84.

Césari, S.N. 1997. Eonotosperma arrondoi Césari gen. et $s p$. nov., a pteridosperm from the Early Carbo- 
niferous of Argentina. Ameghiniana 34(2): 169178.

Césari, S.N., O. Arrondo \& H. van Ameron. 1988. Eusphenopteris Novik a new component of the Gondwana floras. Meded. Rijks Dienst Geol. 42:119. Amsterdam.

Césari, S.N. \& F. Bercowski. 1997. Palinología de la Formación Jejenes (Carbonífero) en la quebrada de Las Lajas, provincia de San Juan, Argentina. Nuevas inferencias paleoambientales. Ameghiniana 34(4): 497-510.

Cladera, G., S. Archangelsky \& J.C. Vega. 2000. Precisiones geográficas, estratigráficas y paleoambientales sobre los niveles portadores de cúpulas pteridospérmicas de la Formación Jejenes, Carbonífero de San Juan, Argentina. Ameghiniana 37, 2: $213-220$

Delevoryas, T. 1955. The medullosae-structure and relationships. Palaeontographica 97: 114-167.

Dunn, M.T., M. Krings, G. Mapes, G.W. Rothwell, R.H. Mapes, \& S. Keqin. 2003. Medullosa steinii sp. nov., a seed fern vine from the Upper Mississippian. Rev. Palaeobot. Palynol. 124:307-324.

Esau, K. 1977. Anatomy of seed plants. John Wiley and Sons, Inc. $2^{\text {nd. }}$ ed. 550pp.

Galtier, J. 1988. Morphology and phylogenetic relationships of early pteridosperms. In C. B. Beck ed. Origin and evolution of gymnosperms Columbia University Press, pp.135-176.

Galtier, J. \& A. Scott. 1991. Stanwoodia, a new genus of probable early gymnosperms from the Dinantian of East Kirkton, Scotland. Trans. R. Soc. Edin-

burgh: Earth Sc., 82:113-123.

Greguss, P. 1955. Identification of living gymnosperms on the basis of xylotomy. Budapest: Akademiai

Kiado. 508 pp.

Griffith, M.M. 1957. Foliar ontongeny in Podocarpus macrophyllus, with special reference to transfusion tissue. Am. J. Bot. 44:705-715.

Gutiérrez, P.R. \& S.N. Césari. 1985. Nuevos elementos microflorísticos de la Formación Jejenes (Carbónico) provincia de San Juan. $1^{\circ}$ Jorn. Geol.

Precordillera: 168-173. San Juan.
Hamer, J.J. \& G.W. Rothwell. 1988. The vegetative structure of Medullosa endocentrica (Pteridospermopsida). Can. J. Bot. 66(2): 375-387

Langdon, L.M. 1920. Stem anatomy of Dioon spinulosum. Bot. Gaz. 70: 110-125.

Leguizamón, R. \& J.C. Vega. 1991. El género Triphyllopteris (morfogénero de frondes) en el Carbonífero de la República Argentina. Ameghiniana 27: 305309

Scheckler, S.E. \& H.P. Banks. 1971. Anatomy and relationships of some Devonian Progymnosperms from New York. Amer. J. Bot. 58: 737-751.

Smoot, E.L. \& T.N. Taylor. 1983. Filamentous microorganisms from the Carboniferous of North America. Can. J. Bot. 61: 2251-2256.

Stein, W.E. 1982. The Devonian plant Reimannia with a discussion of the class Progymnospermopsida.

Palaeontology 25: 605-622.

Stein, W.E. \& C.B. Beck. 1978. Bostonia perplexa gen. et sp. nov., a calamopityacean axis from the New

Albany shale of Kentucky. Am. J. Bot. 65: 459-465. 1992. New information on Bostonia perplexa, an unusual member of the Calamopityaceae from

North America. Rev. Palaeob. Palynol. 72: 73-102. Stewart, W.N. \& G.W. Rothwell. 1993. Paleobotany and the evolution of plants. Cambridge University

Press. 521pp

Taylor, T.N. \& E.L. Taylor. 1993. The biology and evolution of fossil plants. Prentice Hall. 982 pp.

Vega, J.C. \& S. Archangelsky. 1996. Austrocalyx jejenensis Vega and Archangelsky gen. et sp. nov., a cupulate rhacopteroid pteridosperm from the Carboniferous of Argentina. Rev. Palaeob. Palyn. 91: 107-119.

- 1997. The first Gondwana Carboniferous compound cupules and associated seeds. A preliminary note. Rev. Palaeob. Palyn. 99: 55-59.

- 2001. Austrocalyxaceae, a new pteridosperm family from Gondwana. Palaeontographica Abt. B 257:116.

Worsdell, W.C. 1896. The anatomy of the stem of Macrozamia compared with that of other genera of Cycadeae. Ann. Botany 10: 601-620. 